\title{
Corrosion Protection of Copper in Sodium Chloride Solution using Propolis
}

\author{
Ladislav Vrsalovic ${ }^{1, *}$, Senka Gudic ${ }^{1}$, David Gracić, ${ }^{1}$ Ivana Smoljko ${ }^{1}$, Ivana Ivanic ${ }^{2}$, Maja Kliškić ${ }^{1}$, \\ Emeka E. Oguzie \\ ${ }^{1}$ University of Split, Faculty of Chemistry and Technology, Department of Electrochemistry and \\ Materials Protection, Ruđera Boškovića 35, 21000 Split, Croatia \\ ${ }^{2}$ University of Zagreb, Faculty of Metallurgy, Aleja narodnih heroja 3, 44103 Sisak, Croatia \\ ${ }^{3}$ Federal University of Technology Owerri, Electrochemistry and Materials Science Research \\ Laboratory, Department of Chemistry, Owerri, Nigeria \\ *E-mail: ladislav@ktf-split.hr
}

doi: $10.20964 / 2018.02 .71$

Received: 18 October 2017 / Accepted: 4 December 2017 / Published: 28 December 2017

In this investigation the possibility of inhibiting corrosion of copper using ethanol extract of propolis in $0.5 \mathrm{~mol} \mathrm{dm}^{-3} \mathrm{NaCl}$ solution was investigated. The measurements were carried out in $200 \mathrm{~cm}^{3}$ of $\mathrm{NaCl}$ solution to which $4 \mathrm{ml}$ of ethanol extract of propolis was added. Also, the protective effect of propolis coating, which was formed by applying the ethanol extract of propolis to the electrode surface, followed by air drying for $24 \mathrm{~h}$, was investigated. Experiments were performed using electrochemical methods: open circuit potential measurements, linear and potentiodynamic polarization method and electrochemical impedance spectroscopy measurements (EIS). The results showed that the coating of propolis significantly shifted the value of the open circuit potential of $\mathrm{Cu}$ to more positive values, significantly increased the value of polarization resistance and as well led to a reduction in corrosion current density. On the other hand, addition of propolis in solution yielded minor changes in the value of the stable open circuit potential of copper, but increased the value of polarisation resistance and decreased the corrosion current density. After polarisation measurements, the electrode surface was examined by optical microscopy. Quantum chemical modelling of selected constituents of propolis was undertaken in order to ascertain their contributions to the corrosion inhibition performance.

Keywords: copper; corrosion; corrosion inhibition; electrochemical techniques; propolis

\section{$\underline{\text { FULL TEXT }}$}

(C) 2018 The Authors. Published by ESG (www.electrochemsci.org). This article is an open access article distributed under the terms and conditions of the Creative Commons Attribution license (http://creativecommons.org/licenses/by/4.0/). 